\title{
PENERAPAN INFORMASI AKUNTANSI DIFERENSIAL DALAM PENGAMBILAN KEPUTUSAN MEMBELI ATAU MEMBUAT SENDIRI PRODUK SETENGAH JADI PADA UD. BERKAT ANUGERAH
}

\author{
Phamela D Tampubolon \\ David Paul Elia Saerang \\ Agus Toni Poputra
}

\author{
Fakultas Ekonomi dan Bisnis Jurusan Akuntansi \\ Universitas Sam Ratulangi Manado \\ email : phameladesanti@yahoo.com
}

\begin{abstract}
ABSTRAK
Ditengah persaingan usaha yang begitu pesat dan keadaan perekonomian yang tidak menentu, setiap perusahaan dituntut untuk lebih efisien agar dapat bertahan dan semua itu tidak lepas dari peran manajemen. Ukuran yang dipakai manajemen untuk mengukur berhasil tidaknya perusahaan adalah laba. Untuk menghasilkan laba yang efisien manajemen memerlukan informasi akuntansi diferensial untuk memilih tindakan yang terbaik diantara alternatif yang tersedia. Adapun tujuan dari penelitian ini adalah untuk menganalisis penerapan informasi akuntansi diferensial dalam pengambilan keputusan membeli atau membuat sendiri produk setengah jadi pada UD. Berkat Anugerah. Penelitian ini menggunakan metode penelitian deskriptif . Hasil analisis penelitian yang dilakukan pada UD. Berkat Anugerah dilihat dari biaya yang dikeluarkan menunjukan tentang peran akuntansi diferensial dalam pengambilan keputusan jangka pendek, dimana pihak perusahaan sebaiknya membeli produk setengah jadi dari pihak ketiga karena biaya yang dikeluarkan lebih rendah daripada memproduksi sendiri.
\end{abstract}

Kata kunci : akuntansi diferensial, pengambilan keputusan.

\begin{abstract}
Amid competition is so rapid and uncertain economic conditions, every company is required to be more efficient in order tobe more efficient in orderto survive and all of it can not be separated from the role of management. Management measure which is occupied to measure the success or failure of the company is profit. To produce an efficient profit differential accounting information requires management to select the best course of action among alternatives available. The purpose of this study is to analyze the application of differential accounting information in the decision to buy or make your own semi-finished products on UD. Berkat Anugerah. This study uses a descriptive research method. The result of the analysis of research conducted on UD. Berkat Anugerah seen from the cost accounting showed diferential role in the short-term decision making, where the company should buy semi-finished products from third party cost incurred due to lower than producing its own.
\end{abstract}

Keywords : differential accounting, decision-making 


\section{PENDAHULUAN}

\section{Latar Belakang}

Di tengah situasi perekonomian yang tidak menentu sekarang ini, setiap perusahaan dituntut untuk lebih efisien agar dapat bertahan. Sehubungan dengan keadaan ini peran manajemen sangat dibutuhkan dalam membantu perusahaan untuk mencapai tujuannya, yaitu untuk mempertahankan kelangsungan hidup perusahaan dengan mengoptimalkan sumber-sumber daya yang dimiliki perusahaan. Dalam perencanaan, manajemen dihadapkan pada pengambilan keputusan yang menyangkut memilih satu pilihan yang terbaik dari berbagai macam alternatif pilihan. Dalam hal ini manajemen memerlukan informasi yang dapat mengurangi ketidakpastian, sehingga dapat menentukan pilihan yang terbaik bagi perusahaan. Salah satu jenis informasi yang dibutuhkan oleh manajemen sebagai dasar perencanaan dan pengambilan keputusan adalah informasi akuntansi diferensial (differential accounting information). Manajemen membutuhkan informasi akuntansi diferensial ini untuk memilih altenatif tindakan yang terbaik diantara alternatif yang tersedia, pemilihan alternatif akuntansi diferensial mempunyai dua karakteristik, yaitu informasi masa yang akan datang dan informasi berbeda diantara alternatif yang akan diambil oleh pengambil keputusan. Pada informasi akuntansi diferensial, umumnya manajemen menghadapi empat macam pengambilan keputusan dalam jangka pendek, yaitu membeli atau membuat sendiri, menjual atau memproses lebih lanjut suatu produk, menghentikan atau melanjutkan produksi produk tertentu atau kegiatan usaha suatu bagian perusahaan, menerima atau menolak pesanan khusus. Setiap keputusan yang diambil manajemen harus dapat dipertanggungjawabkan dan memiliki dasar yang relevan. UD. Berkat Anugerah yang menjadi objek dari penelitian ini memiliki tujuan usaha mengoptimalkan laba, sebagaimana usaha-usaha yang lain. Adakalanya perusahaan mengalami kesulitan dalam pengambilan keputusan membeli atau membuat sendiri produk setengah jadi, berupa rangka kayu untuk set kursi tamu. Dalam kondisi seperti ini manajemen memerlukan informasi akuntansi diferensial yang dapat dijadikan bahan pertimbangan dalam pengambilan keputusan membeli atau membuat sendiri, dengan taksiran penghematan biaya yang dapat dilakukan oleh perusahaan. Informasi akuntansi diferensial dapat mengukur seberapa besar biaya diferensial yang terjadi jika manajemen memilih suatu alternatif, sehingga manajemen dapat memperoleh perbandingan biaya yang terjadi dari alternatif-alternatif tersebut.

\section{Tujuan Penelitian}

Tujuan yang ingin dicapai dalam penelitian ini adalah untuk mengetahui dan menganalisis penerapan informasi akuntansi diferensial dalam proses pengambilan keputusan membeli atau membuat sendiri produk setengah jadi pada UD. Berkat Anugerah.

\section{TINJAUAN PUSTAKA}

\section{Akuntansi Manajemen}

Akuntansi manajemen adalah proses pengidentifikasian, pengukuran, penghimpunan, penganalisisan, penyusunan, penafsiran dan pengkomunikasian informasi keuangan yang digunakan oleh manajemen untuk merencanakan, mengevaluasi, dan mengendalikan kegiatan usaha di dalam sebuah organisasi, serta untuk memastikan penggunaan dan akuntabilitas sumber daya yang tepat. (Simamora 2012:13).

\section{Akuntansi Manajemen sebagai Suatu Tipe Informasi}

Informasi merupakan salah satu fakta, data, pengamatan, persepsi, atau suatu yang lain yang menambah pengetahuan. informasi akuntansi manajemen diperlukan pada seluruh tahap proses manajemen mulai dari perencanaan, koordinasi, pengendalian sampai dengan tahap pengambilan keputusan. (Halim dkk.2013:9), Pengambilan keputusan selalu menyangkut masa yang akan datang, yang mengandung ketidakpastian dan selalu menyangkut pemilihan suatu alternatif tindakan diantara sekian banyak alternatif yang tersedia. Oleh karena itu, pengambilan keputusan selalu berusaha mengumpulkan informasi untuk mengurangi ketidakpastian yang dihadapi dalam memilih alternatif tindakan tersebut.

Mulyadi yang dikutip oleh Partomuan (2010) mengemukakan informasi akuntansi sebagai bahasa bisinis dikelompokkan menjadi tiga golongan,yaitu sebagai berikut.

a. Informasi Operasi

Untuk melaksanakan aktivitas perusahaan sehari-hari, manajemen memerlukan berbagai informasi seperti jumlah kilogram bahan baku yang dipakai dalam produksi, jumlah sediaan produk jadi yang ada digudang, jumlah produksi hari ini, jumlah jam kerja karyawan dalam satu minggu, dan jumlah produk 
yang dijual hari ini. Informasi operasi ini merupakan bahan baku untuk mengolah tipe informasi akuntansi yang lain : informasi akuntansi keuangan dan informasi akuntansi manajemen.

b. Informasi Akuntansi Keuangan

Informasi akuntansi keuangan diperlukan baik oleh manajemen maupun pihak luar perusahaan untuk pengambilan keputusan guna menentukan hubungan antara pihak tersebut dengan perusahaan. Informasi akuntansi keuangan ini dihasilkan oleh sistem pengolahan informasi keuangan yang disebut akuntansi keuangan.

c. Informasi Akuntansi Manajemen

Informasi akuntansi manajemen diperlukan oleh manajemen untuk melaksanakan dua fungsi pokok manajemen, yaitu: perencanaan dan pengendalian aktivitas perusahaan.

\section{Jenis Informasi Akuntansi Manajemen}

Halim dkk. (2013:10) menjelaskan bahwa, informasi akuntansi manajemen dibagi menjadi 3 jenis yaitu: (1) informasi akuntansi penuh/menyeluruh (full accounting information); (2) informasi akuntansi pertanggungjawaban (responsibility accounting); dan (3) informasi akuntansi diferensial (differential accounting). Penjelasannya sebagai berikut.

a. Informasi Akuntansi Penuh (Full Accounting Information)

Akuntansi penuh menyajikan informatika mengenai pendapatan total, biaya total dan atau aktiva total baik pada masa lalu maupun masa yang akan datang, terutama yang berkaitan dengan biaya atau disebut dengan informasi akuntansi biaya penuh. Informasi mengenai biaya penuh masa lalu (historical full cost) digunakan untuk penyusunan laporan keuangan (umumnya berupa neraca dan laporan laba rugi).

b. Informasi Akuntansi Pertanggungjawaban (Responsibility Accounting Information).

Akuntansi pertanggungjawaban menyajikan informasi mengenai pendapatan, biaya atau aktiva yang dikaitkan dengan suatu bagian atau unit di dalam perusahaan. Informasi akuntansi pertanggungjawaban masa lalu bermanfaat untuk menganalisis prestasi dari masing-masing manajer pusat pertanggungjawaban. Informasi akuntansi pertanggungjawaban yang menyangkut masa yang akan datang digunakan dalam kegiatan perencanaan tahunan (anggaran/budget).

c. Informasi Akuntansi Diferensial (Differential Accounting Information)

Akuntansi diferensial menyajikan informasi mengenai taksiran pendapatan, biaya dan atau aktiva yang berbeda jika suatu tindakan tertentu dipilih, dibandingkan dengan alternatif tindakan lain. Informasi akuntansi diferensial berkaitan dengan masa yang akan datang.

\section{Informasi Akuntansi Diferensial}

Informasi akuntansi diferensial merupakan informasi akuntansi yang dihubungkan dengan pemilihan alternatif. Informasi Akuntansi diferensial merupakan taksiran perbedaan aktiva, pendapatan, dan/atau biaya dalam alternatif tindakan yang lain. (Sunarto 2008:57).

\section{Pengambilan Keputusan}

Syamsi (2009:10) menyatakan bahwa pengambilan keputusan merupakan tindakan pimpinan untuk memecahkan masalah yang dihadapi dalam organisasi yang dipimpinnya dengan melalui pemilihan satu diantara alternatif-alternatif yang dimungkinkan.

\section{Tahap-tahap Pengambilan Keputusan}

Mulyadi (2007:108), mengungkapkan bahwa, pengambilan keputusan dilaksanakan melalui empat tahap, yaitu sebagai berikut.

a. Pengakuan dan perumusan masalah atau kesempatan.

b. Pencarian Tindakan Alternatif dan Kuantifikasi Konsekuensinya Masing-masing.

c. Pemilihan Alternatif Optimum atau Alternatif yang Memuaskan

d. Implementasi dan Penindaklanjutan

\section{Manfaat Akuntansi Diferensial Dalam Pengambilan Keputusan Jangka Pendek}

Bastian dan Nurlela (2007:175), menyatakan ada beberapa manfaat akuntansi diferensial dalam pengambilan keputusan jangka pendek yang pada umumnya dihadapi oleh manajemen dalam pengambilan keputusan yang umumnya terdiri dari empat macam keputusan, yaitu sebagai berikut.

a. Menjual atau memproses lebih lanjut (sell or process futher) 
Ada kalanya manajemen puncak dihadapkan pada pemilihan menjual produk tertentu pada kondisinya sekarang atau memprosesnya lebih lanjut menjadi produk yang lebih tinggi harga jualnya. Dalam pengambilan keputusan macam ini, informasi akuntansi diferensial yang diperlukan oleh manajemen adalah pendapatan diferensial dengan biaya diferensial jika alternatif memproses lebih lanjut dipilih.

b. Menghentikan atau melanjutkan produksi produk tertentu atau kegiatan usaha departemen tertentu (stop or continue product line).

Dalam menghadapi kondisi ini, manajemen perlu mempertimbangkan keputusan menghentikan atau tetap melanjutkan produksinya. Dan informasi yang relevan untuk dipertimbangkan dalam pengambilan keputusan ini adalah biaya diferensial dan pendapatan diferensial.

c. Menerima atau menolak pesanan khusus (special order decision).

Penerapan analisis biaya diferensial juga dapat digunakan untuk membuat keputusan menerima atau menolak pesanan khusus apabila kapasitas mesin perusahaan masih terdapat kapasitas yang menganggur dan pada saat itu harga jualnya dibawah harga pokok produksi dalam hitungan biaya penuh.

d. Membeli atau membuat sendiri (make or buy decision)

Pertimbangan untuk membeli atau membuat sendiri dapat juga timbul sebagai akibat adanya taksiran penghematan biaya jika suatu komponen yang sebelumnya dibeli dari pemasok luar direncanakan akan dibuat sendiri oleh perusahaan.

\section{Keputusan Membeli atau Membuat Sendiri Produk}

Carter (2009:330) menyatakan, tujuan dari keputusan buat atau beli sebaiknya adalah penggunaan optimal atas sumberdaya produksi dan keuangan perusahaan. Masalah yang seringkali muncul dalam kaitannya dalam pengambilan keputusan membeli atau membuat sendiri adalah ruangan yang tak terpakai, buruh yang menganggur dan perhitungan biaya. Dalam kondisi ini manajer cenderung untuk mempertimbangkan pembuatan unit-unit tertentu dibanding membelinya dengan maksud untuk memanfaatkan fasilitas-fasilitas yang ada.

\section{Penelitian Terdahulu}

Tabel 1 Penelitian Terdahulu

\begin{tabular}{|c|c|c|c|c|c|c|}
\hline $\begin{array}{c}\text { Nama } \\
\text { Peneliti/ } \\
\text { Tahun } \\
\end{array}$ & Judul & Tujuan & $\begin{array}{c}\text { Metode } \\
\text { Penelitian }\end{array}$ & Hasil & Persamaan & Perbedaan \\
\hline $\begin{array}{c}\text { Maulida } \\
\text { (2012) }\end{array}$ & $\begin{array}{l}\text { Analisis } \\
\text { Informasi } \\
\text { Akuntansi } \\
\text { Diferensial } \\
\text { dalam } \\
\text { pengambilan } \\
\text { keputusan } \\
\text { membeli atau } \\
\text { membuat sendiri } \\
\text { bahan baku mie } \\
\text { pada Usaha Mie } \\
\text { ayam Wonogiri }\end{array}$ & $\begin{array}{l}\text { Menganalisis } \\
\text { peranan } \\
\text { informasi } \\
\text { akuntansi } \\
\text { diferensial } \\
\text { dalam } \\
\text { pengambilan } \\
\text { keputusan } \\
\text { membeli atau } \\
\text { membuat } \\
\text { sendiri bahan } \\
\text { baku mie }\end{array}$ & Deskriptif & $\begin{array}{l}\text { Peran dari } \\
\text { akuntansi } \\
\text { diferensial } \\
\text { dalam } \\
\text { pengambilan } \\
\text { suatu keputusan } \\
\text { jangka pendek, } \\
\text { dimana pihak } \\
\text { perusahaan } \\
\text { membuat sendiri } \\
\text { bahan baku Mie, } \\
\text { karena biaya } \\
\text { produksi yang } \\
\text { dikeluarkan } \\
\text { apabila } \\
\text { membuat sendiri } \\
\text { lebih rendah } \\
\text { dari pada } \\
\text { membeli dari } \\
\text { luar }\end{array}$ & $\begin{array}{l}\text { Menggunakan } \\
\text { analisis } \\
\text { deskriptif } \\
\text { serta } \\
\text { menganalisis } \\
\text { tentang } \\
\text { akuntansi } \\
\text { diferensial }\end{array}$ & $\begin{array}{l}\text { objek } \\
\text { penelitian,latar } \\
\text { belakang } \\
\text { masalah dan } \\
\text { tujuan } \\
\text { penelitian yang } \\
\text { berbeda. }\end{array}$ \\
\hline
\end{tabular}




\begin{tabular}{|c|c|c|c|c|c|c|}
\hline $\begin{array}{c}\text { Jatmiko } \\
(2012)\end{array}$ & $\begin{array}{l}\text { Analisis } \\
\text { Informasi } \\
\text { Akuntansi } \\
\text { Diferensial } \\
\text { dalam } \\
\text { Pengambilan } \\
\text { Keputusan } \\
\text { Menerima atau } \\
\text { Menolak } \\
\text { Pesanan Khusus } \\
\text { Sepatu pada } \\
\text { Perusahaan } \\
\text { Sepatu Asia }\end{array}$ & $\begin{array}{l}\text { Mengetahui dan } \\
\text { memperoleh } \\
\text { gambaran } \\
\text { dengan jelas } \\
\text { tentang } \\
\text { penggunaan } \\
\text { analisis } \\
\text { informasi } \\
\text { diferensial } \\
\text { dalam } \\
\text { pengambilan } \\
\text { keputusan } \\
\text { menerima atau } \\
\text { menolak } \\
\text { pesanan khusus } \\
\text { sepatu apakah } \\
\text { akan } \\
\text { menimbulkan } \\
\text { laba/rugi } \\
\text { perusahaan }\end{array}$ & Deskriptif & $\begin{array}{l}\text { Perusahaan } \\
\text { memperoleh } \\
\text { laba untuk } \\
\text { pesanan khusus } \\
\text { sepatu pada } \\
\text { bulan november } \\
\text { 2011, walaupun } \\
\text { harga yang } \\
\text { diminta } \\
\text { perusahaan } \\
\text { lebih rendah } \\
\text { dari harga jual } \\
\text { normal }\end{array}$ & $\begin{array}{l}\text { Menggunakan } \\
\text { analisis } \\
\text { deskriptif serta } \\
\text { menganalisis } \\
\text { tentang } \\
\text { akuntansi } \\
\text { diferensial }\end{array}$ & $\begin{array}{l}\text { Objek } \\
\text { penelitian, } \\
\text { latar } \\
\text { belakang } \\
\text { masalah dan } \\
\text { tujuan } \\
\text { penelitian } \\
\text { yang } \\
\text { berbeda. }\end{array}$ \\
\hline
\end{tabular}

\section{METODE PENELITIAN}

\section{Jenis Penelitian}

Penelitian ini menggunakan tingkat ekspalasi deskriptif yaitu pengumpulan data untuk mendeskripsikan suatu fenomena yang sama seperti pada waktu penelitian dilakukan. Analisis deskriptif digunakan untuk menjelaskan hasil penelitian berupa angka secara naratif. Sesuai dengan penelitian pengumpulan data didapatkan dalam bentuk angka-angka yang kemudian dijelaskan secara naratif sesuai hasil penelitian yang didapat dari objek penelitian yaitu UD. Berkat Anugerah.

\section{Tempat dan Waktu Penelitian}

Tempat yang menjadi penelitian ini adalah UD.Berkat Anugerah yang bertempat di Jl.Santiago kompleks puskesmas Tuminting.,Kecamatan Tuminting . Waktu penelitian secara keseluruhan dilakukan selama 2 bulan, sejak bulan september 2013 sampai oktober 2013.

\section{Prosedur Penelitian}

Prosedur penelitian yang dilakukan adalah sebagai berikut:

a. Survei objek penelitian.

b. Mengambil data-data perusahaan dan wawancara.

c. Membandingkan dan mengolah data-data dan informasi perusahaan dengan dasar teori yang digunakan.

d. Membuat kesimpulan dan memberikan saran.

\section{Metode Pengumpulan Data}

\section{Jenis Data}

Kuncoro (2004:25) menyatakan jenis data dibedakan atas dua jenis yaitu data kuanitatif dan data kualitatif. Jenis data yang digunakan dalam penelitan ini adalah data kuantitaif dan data kualitatif. Data kualitatif dalam penelitan ini yaitu data yang diperoleh melalui berbagai macam teknik pengumpulan data misalnya wawancara, analisis dokumen, atau observasi., seperti wawancara mengenai proses pengambilan keputusan membeli atau memproduksi sendiri produk setengah jadi. Sedangkan data kuantitatif dalam penelitian ini berupa data-data biaya produksi dalam perusahaan. 


\section{Sumber Data}

Kuncoro (2004:25) menyatakan, berdasarkan sumbernya data penelitian dapat dikelompokkan menjadi 2 yaitu data primer dan data sekunder. Data primer adalah data yang diperoleh atau dikumpulkan oleh peneliti secara langsung dari sumber datanya. seperti wawancara dengan pemilik UD.Berkat Anugerah. Data Sekunder adalah data yang diperoleh atau dikumpulkan peneliti dari berbagai sumber yang telah ada. pada penelitian ini diperoleh dari bahan-bahan yang tersedia di buku-buku dan sumber-sumber lain yang berhubungan dengan penelitian ini

\section{Teknik Pengumpulan Data}

Dalam penelitian ini, penulis menggunakan metode pengumpulan data adalah sebagai berikut.

a. Wawancara, yaitu teknik pengumpulan data yang dilakukan dan diperoleh dengan mengadakan tanya jawab sambil tatap muka antara pewawancara dengan informan. Seperti melakukan wawancara langsung dengan pemilik dan karyawan-karyawan pada UD. Berkat Anugerah mengenai proses produksi..

b. Observasi, yaitu mengadakan pengamatan langsung pada tempat penelitian untuk mendapatkan data-data yang diperlukan sehubungan dengan kepentingan penelitian.

c. Studi kepustakaan, yaitu menggunakan buku-buku dari berbagai sumber untuk mendapatkan data yang bersifat teoritis

\section{Metode Analisis Data}

Metode yang digunakan dalam penelitian ini adalah, metode analisis deskriptif yaitu suatu metode pembahasan permasalahan yang sifatnya menguraikan, menggambarkan, membandingkan dan menerangkan suatu data atau keadaan yang bertujuan untuk mendapatkan gambaran yang lebih jelas dan terperinci mengenai suatu keadaan berdasarkan data atau informasi yang telah didapatkan, kemudian dikumpulkan sehingga didapatkan informasi yang diperlukan untuk menganalisa masalah yang ada.

\section{HASIL PENELITIAN DAN PEMBAHASAN}

\section{Sejarah Singkat UD. Berkat Anugerah}

Perusahaan Meubel UD. Berkat Anugerah berdiri pada Tahun 2007, usaha ini merupakan usaha keluarga yang didirikan oleh Bapak Bony Husain dan Ibu Ribka Bulahari berlokasi di Kecamatan Tuminting Kota Manado. Pendirian usaha ini berdasarkan pemikiran untuk pengembangan usaha keluarga serta penyerapan tenaga kerja yang tersedia diwilayah tersebut. Produk yang dihasilkan Perusahaan Meubel UD. Berkat Anugerah diantaranya adalah sebagai berikut.
a. Meja dan Kursi Tamu
b. Lemari Pajangan
c. 1 set meja makan
d. Lemari Pakaian

\section{Deskripsi Kerja}

Perusahaan Meubel Berkat Anugerah mempunyai beberapa karyawan yang terdiri dari berikut ini.

Tabel 2 Tenaga Kerja UD.Berkat Anugerah

\begin{tabular}{lc}
\hline \multicolumn{1}{c}{ Uraian } & $\begin{array}{c}\text { Jumlah } \\
\text { Karyawan }\end{array}$ \\
\hline Bagian Administrasi dan Keuangan & 2 orang \\
Bagian Kontrol & 1 orang \\
Bagian Perakitan & 2 orang \\
Bagian Pemasangan & 1 orang \\
Bagian Penjahitan & 2 orang \\
Bagian Pengecatan & 2 orang \\
Bagian Finishing & 1 orang \\
TOTAL & $\mathbf{1 1}$ orang \\
\hline
\end{tabular}

Sumber : UD. Berkat Anugerah 


\section{Hasil Penelitian \\ Peranan Informasi Akuntansi Diferensial dalam Pengambilan Keputusan}

Perusahaan Meubel UD. Berkat Anugerah dituntut untuk melakukan perencanaan dengan baik bagi kelancaran kegiatan perusahaan. Dalam perencanaan, perusahaan dihadapkan pada pengambilan keputusan yang menyangkut pemilihan berbagai alternatif. Untuk memutuskan alternatif mana yang harus dipilih, perusahaan dihadapkan pada ketidakpastian. Oleh karena itu manajemen perusahaan Meubel UD. Berkat Anugerah memerlukan informasi yang dapat mengurangi ketidakpastian sehingga memungkinkan perusahaan menentukan pilihan yang baik pada alternatif yang ada. Salah satu informasi yang diperlukan adalah informasi akuntansi diferensial. Perusahaan Meubel UD. Berkat Anugerah membutuhkan informasi akuntansi diferensial dalam setiap tahap pengambilan keputusan terutama menyangkut pengadaan produk setengah jadi pada perusahaan berkaitan dengan alternatif membeli atau membuat sendiri produk setengah jadi tersebut. Perusahaan Meubel UD. Berkat Anugrah memproduksi beberapa produk meubel berbahan kayu, namun yang akan penulis bahas dalam penulisan ini ada produk kursi dan meja tamu yang merupakan produk yang paling banyak diproduksi oleh perusahaan.

\section{Membeli Produk Setengah Jadi dari Ketiga}

Perusahaan membeli rangka kayu sebagai bahan baku utama dibeli dari Kota Jepara, dengan menggunakan konteiner dimana dalam satu konteiner berisi sebanyak 100 set kursi dan meja tamu. Adapun dalam sekali pengiriman biaya yang dikeluarkan Rp111.000.000,00.

Tabel 3 Membeli Produk Setengah Jadi dari Ketiga

\begin{tabular}{ccccc}
\hline Uraian & Unit & $\begin{array}{c}\text { Harga } \\
\text { Pembelian/ } \\
\text { Konteiner } \\
(\mathbf{R p})\end{array}$ & Kuantitas & $\begin{array}{c}\text { Harga per set } \\
\text { (Rp) }\end{array}$ \\
\hline A & B & C & D & E=C/D \\
Rangka Kayu & Set & 111.000 .000 & 100 & 1.110 .000 \\
\hline
\end{tabular}

Sumber : UD. Berkat Anugerah (data diolah,2013)

Tabel 4 Membuat Sendiri Produk Setengah Jadi

\begin{tabular}{lcc}
\hline & $\begin{array}{c}\text { Per set } \\
(\mathbf{R p})\end{array}$ & \multicolumn{1}{c}{$\begin{array}{c}\text { 100 set } \\
(\mathbf{R p})\end{array}$} \\
\hline Biaya bahan baku & & \\
$\begin{array}{l}\text { Kayu 1/2 } \mathrm{M}^{3} \text { x Rp 1.800.000 } \\
\text { Biaya tenaga kerja langsung : }\end{array}$ & 900.000 & 90.000 .000 \\
$\begin{array}{l}\text { 4 hari x Rp 50.000 } \\
\text { Biaya Overhead pabrik variabel : }\end{array}$ & 200.000 & 20.000 .000 \\
$\begin{array}{l}\text { Listrik } \\
\text { Biaya overhead pabrik tetap: }\end{array}$ & 18.000 & 1.800 .000 \\
$\begin{array}{l}\text { Paku } \\
\text { Biaya overhead pabrik tetap bersama : }\end{array}$ & 4.500 & 450.000 \\
Pengawas & 30.000 & 3.000 .000 \\
& & \\
Jumlah biaya produksi & 1.152 .500 & 115.250 .000 \\
\hline
\end{tabular}

Sumber : UD. Berkat Anugerah (data diolah,2013) 


\section{Pembahasan}

Setiap perusahaan menjalankan usahanya tidak luput dari berbagai macam masalah. Masalah yang dihadapi tidak dapat diabaikan begitu saja, karena secara langsung ataupun tidak langsung dapat menghambat pencapaian tujuan perusahaan. Oleh karena itu sangat diperlukan pemecahan yang tepat atas masalah yang dihadapi. Perusahaan Meubel UD. Berkat Anugerah ini pun tidak terlepas dari masalah-masalah dalam menjalankan operasinya. Salah satu diantaranya membuat atau membeli produk setengah jadi. Dalam penyelesaian masalah ini diperlukan pertimbangan dan perhitungan yang cermat dari manajemen agar keputusan yang diambil tidak merugikan perusahaan.

Sehubungan dengan kegiatan produksi produk setengah jadi yang dilakukan oleh perusahaan maka yang menjadi titik pokok dalam pembahasan ini adalah penerapan informasi akuntansi diferensial dalam pengambilan keputusan membuat atau membeli sendiri produk setengah jadi pada perusahaan Meubel UD.Berkat Anugerah. Dalam upaya untuk memperoleh laba yang optimal dari hasil produksinya, maka pihak manajemen perusahaan perlu mengelolah kegiatan produksinya secara efektif dan efisien, khususnya pada proses produksi produk setengah jadi sehingga dapat dijadikan sebagai alat pengambilan keputusan.

Informasi akuntansi diferensial yang ada di perusahaan bukanlah semata-mata sebagai bahan pengambilan keputusan, akan tetapi lebih banyak berperan untuk mengumpulkan data informasi relevan dan menganalisa informasi tersebut, sehingga dapat disajikan informasi yang benar-benar siap untuk digunakan sebagai dasar pengambilan keputusan. Dengan semakin meningkatnya persaingan dan untuk mendapatkan keuntungan yang optimal, perusahaan mencoba menganalisis masalah ini. Dalam memecahkan masalah yang dihadapi ini, terdapat dua alternatif yang dapat dipilih oleh perusahaan yaitu sebagai berikut.

1. Perusahaan membuat sendiri produk setengah jadi,

2. Perusahaan membeli produk setengah jadi dari pemasok luar

Untuk menganalisis kemungkinan perusahaan membeli dari pemasok luar atau membuat sendiri produk setengah jadi untuk memenuhi pesanan, perusahaan mengambil produk set meja tamu karena produk ini merupakan produk yang paling banyak diproduksi oleh perusahaan. Dalam hal ini penulis akan mencoba membantu pihak manajemen perusahaan Meubel UD.Berkat Anugerah dalam menganalisis apakah lebih baik membeli atau memproduksi sendiri produk setengah jadi untuk memenuhi pesanan.

Keputusan membuat atau membeli sendiri dihadapi manajemen terutama dalam perusahaan yang produknya terdiri dari berbagai komponen dan yang memproduksi berbagai jenis produk. Tidak selamanya komponen yang membentuk produk harus diproduksi sendiri oleh perusahaan, jika memang pemasok dari luar dapat memasok komponen dengan harga yang lebih murah daripada biaya yang ditimbulkan dari membuat sendiri. Alternatif tersebut timbul karena penerapan informasi akuntansi diferensial seta adanya pemasok dari luar yang menyediakan produk setengah jadi dengan harga yang relatif. Ini pula yang memungkinkan manajemen perusahaan Meubel UD.Berkat Anugerah yang sebelumnya memproduksi sendiri produk setengah jadinya, kemudian mempertimbangkan membeli produk setengah jadi dari pemasok.

Berdasarkan tabel 3 dan 4 terlihat perbedaan biaya apabila perusahaan membeli atau membuat sendiri produk setengah jadi seperti yang diperlihatkan seperti berikut.

Tabel 5 Perbedaan biaya membeli atau membuat sendiri produk setengah jadi

\begin{tabular}{cccc}
\hline \multicolumn{2}{c}{$\begin{array}{c}\text { Biaya diferensial } \\
\text { per set }\end{array}$} & \multicolumn{2}{c}{$\begin{array}{c}\text { Biaya Diferensial } \\
\text { Total (100 set) }\end{array}$} \\
\hline $\begin{array}{c}\text { Membuat } \\
\text { (Rp) }\end{array}$ & $\begin{array}{c}\text { Membeli } \\
(\mathbf{R p})\end{array}$ & $\begin{array}{c}\text { Membuat } \\
(\mathbf{R p})\end{array}$ & $\begin{array}{c}\text { Membeli } \\
(\mathbf{R p})\end{array}$ \\
1.152 .500 & 1.110 .000 & 115.250 .000 & 111.000 .000 \\
42.500 & & 4.250 .000 & \\
\hline
\end{tabular}

Sumber : UD. Berkat Anugerah (data diolah,2013)

Dari hasil analisis diatas,ternyata membeli produk setengah jadi dari pihak ketiga lebih menguntungkan dibandingkan dengan membuat sendiri produk setengah jadi. 


\section{PENUTUP}

\section{Kesimpulan}

Berdasarkan keseluruhan penelitian yang dilakukan ditarik kesimpulan yaitu, UD. Berkat Anugerah telah memperhatikan aspek-aspek yang berperanpenting dalam pengambilan keputusan. sehingga keputusan yang diambil telah melalui berbagai pertimbangan. Penerapan Informasi akuntansi diferensial berperan dalam membantu manajemen untuk memilih alternatif terbaik sehingga diperoleh perbedaan biaya apabila UD. Berkat Anugerah memilih alternatif untuk memproduksi sendiri produk setengah jadinya maka perusahaan perlu menambah biaya sebesar Rp 42.500 per set produk setengah jadi dan Rp 4.250.000 untuk produksi 100 set.

\section{Saran}

Berdasarkan hasil pembahasan mengenai penerapan informasi akuntansi diferensial dalam pengambilan keputusan membeli atau membuati sendiri produk setengah jadi, maka dikemukakan saran yang dapat dijadikan bahan pertimbangan perusahaan untuk meningkatkan aktivitas perusahaan dalam mencapai tujuan perusahaan yaitu setelah penelitian ini dilakukan sebaiknya UD.Berkat Anugerah tetap pada keputusan untuk membeli sendiri produk setengah jadinya untuk produk tertentu, karena pertimbangan biaya yang dikeluarkan. Hal tersebut tentunya akan berpengaruh pada laba yang akan diperoleh oleh perusahaan.

\section{DAFTAR PUSTAKA}

Bastian, Bustami., Nurlela.2007. Akuntansi Biaya, Melalui Pendekatan Manajerial. Mitra Wacana. Yogyakarta.

Carter, William K. 2009. Akuntansi Biaya. Salemba empat. Jakarta

Halim, Abdul., Soepomo Bambang., Syam Kusufi Muhammad. 2013. Akuntansi Manajemen Edisi 2. BPFE. Yogyakarta

Syamsi,Ibnu. 2009. Pengambilan Keputusan dan Sistem Informasi. Bumi Aksara. Jakarta.

Jatmiko, Agustinus. 2012. Analisis Informasi Akuntansi Diferensial dalam Pengambilan Keputusan Menerima atau Menolak Pesanan Khusus Sepatu pada Perusahaan Sepatu Asia Skripsi. Universitas Gunadarma.Cirebon.

Kuncoro, Mudrajad. 2004. Metode Riset Untuk Bisnis dan Ekonomi. Erlangga. Jakarta.

Maulida, Yulita.2012. Analisis Informasi Akuntansi Diferensial dalam Keputusan Membeli atau Membuat Sendiri Bahan Baku Mie pada Usaha Ayam Mie Wonogiri. Skripsi .Universitas Gunadarma.Cirebon.

Mulyadi. 2007.Sistem Perencanaan dan Pengendalian Manajemen . Edisi Ketiga. Salemba Empat. Jakarta..

Partomuan, Johanis. 2010. Analisis Penerapan Informasi Akuntansi Manajemen dalam Proses Pengambilan Keputusan pada PDAM Tirtamadi Medan. Skripsi.Universitas Sumatera Utara.Medan

Simamora,H. 2012. Akuntansi Manajemen. Edisi Ketiga. Star Gate Publisher. Riau

Sunarto. 2008. Akuntansi Manajemen. Amus. Yogyakarta. 